\title{
RESEARCH
}

Open Access

\section{Characteristics and classification of landslide dams associated with the 2008 Wenchuan earthquake}

\author{
Xuanmei Fan ${ }^{1 *}$, Qiang Xu' ${ }^{1}$ Cees J. van Westen², Runqiu Huang ${ }^{1}$ and Ran Tang ${ }^{1}$
}

\begin{abstract}
Background: Strong earthquakes are among the prime triggering factors of landslides, which may block rivers, forming landslide dams. Some of these dams may pose serious threats to people and property due to upstream inundation and downstream dam-breach flooding. Evaluating the stability and potential hazard of landslide dams is significant for the mitigation measures, but remains challenging. The 2008 Wenchuan earthquake $\left(M_{w} 7.9\right)$ in China triggered numerous landslides over a broad area, some of which dammed rivers, posing severe threats to downstream settlements. Our previous study created one of the most complete landslide dam inventories including detailed geomorphic parameters of 828 landslide dams induced by the Wenchuan earthquake. This paper presents the study of a number of representative landslide dams associated with the 2008 Wenchuan earthquake.

Results: The coseismic landslides were classified into rock/debris avalanches, debris flows, rock/debris slides and rock falls. According to dam composition material and sedimentological features, landslide dams were categorized into three types: dams mainly composed of large boulders and blocks; dams composed of unconsolidated fine debris; and dams with partly intact rock strata at the base topped by large boulders and blocks or soil with rock fragments, showing two-layered or three-layered depositional structure. This classification is linked to the typology of damming landslides and considered to be a preliminary indicator of dam stability. In addition, dam stability also largely depends on valley morphometry as well as landslide runout distance and mechanism. The post-earthquake debris flow damming events induced by subsequent rainfalls are also introduced. It was found that there is still a large amount of loose sediment remaining on the slope, which may continue promoting heavy debris flows and dams in the coming years or decades.

Conclusions: The classification of landslide dams proposed in this study can be used as a preliminary indicator of dam stability. More reliable assessment requires a geotechnical approach taking into account a variety of dynamic loading scenarios, and also relies on knowledge about the accurate dam and barrier-lake geometry. There is still a large amount of loose sediment remaining on the slopes, which may be reactivated and remobilized during the heavy post-earthquake rainstorms. Therefore, predicting the post-earthquake debris flows and evaluating their potential for damming rivers are still of great concern and remain as a main challenge.
\end{abstract}

Keywords: Landslide, Landslide dam, Wenchuan earthquake, Stability, Classification

\footnotetext{
* Correspondence: fxm_cdut@qq.com

${ }^{1}$ The State Key Laboratory of Geohazards Prevention and Geoenvironment

Protection, Chengdu University of Technology, Chengdu, Sichuan,

China610059

Full list of author information is available at the end of the article
} 


\section{Background}

Landslide dams are common worldwide, especially in tectonically active mountain regions (Costa and Schuster 1988; Korup 2004; Evans et al. 2011). They are extremely dangerous phenomena, as they may trigger devastating dam-break floods that can affect large areas downstream. A landslide dam can form in a wide range of geological and geomorphological settings, from high alpine debris avalanches to quick-clay failures in wide valley floors. According to the analysis of 390 landslide dams worldwide (Schuster 1993), earth slumps and rock slides are the most common mass movements triggering blockage of fluvial systems (50\%), followed by debris, mud and earth flows (25\%), rock and debris avalanches (19\%), sensitive clay failures as well as rock and earth falls (6\%). Most of the landslide dams (>80\%) were induced by rainstorms/snowmelts and earthquakes (Schuster 1993; Peng and Zhang 2012), although other less common causes, such as volcanic and anthropogenic activity (Asanza et al. 1992) have been documented. The triggers and damming-landslide types vary in different regions. For example, Korup (2004) studied 232 landslide dams in New Zealand, and found that the triggering mechanism of $59 \%$ landslide dams remain unexplained, 39\% were triggered by earthquakes, and only $3 \%$ were formed during high-intensity rainstorms. In addition, rock avalanches are the most common type and account for $27 \%$ of the data in New Zealand, while Ermini and Casagli (2003) found that sliding processes involving rotational and translational movements are the most frequent landslide type causing blockage (more than $40 \%$ of the 353 cases), followed by rock avalanches (17\%) and debris flows (14\%).

In 2008 a devastating earthquake with a magnitude of $M_{w} 7.9$ hit China's Sichuan Province, being the largest seismic event in China in more than 50 years. It triggered numerous landslides over a broad area, some of which dammed rivers, posing severe threats to downstream settlements. Cui et al. (2009) identified 257 landslide dams triggered by the Wenchuan earthquake and made a preliminary risk evaluation of some key landslide-dammed lakes. Fan et al. (2012a) created one of the most complete landslide dam inventories including detailed geomorphic parameters of 828 landslide dams. In order to avoid the potential hazard of dambreak floods, the Chinese army created artificial spillways in 32 of the dams using explosives and heavy machinery. Xu et al. (2009a) evaluated the hazard of these 32 dams by considering dam height, dam composition materials and maximum capacity of the landslidedammed lakes. Wang et al. (2008) and Liu et al. (2009) numerically modelled the Tangjiashan landslide, and Liou et al. (2010) as well as Xu et al. (2010) detected the changes of its barrier lake based on satellite image classification. Fan et al. (2012b) created an integrated approach that combines the physically-based BREACH model and the 1D-2D SOBEK hydrodynamic model to simulate the potential dam-break floods of the Tangjiashan landslide dam in different scenarios.

Given the relatively short longevity of landslide dams, evaluating their stability and potential hazard is significant for the mitigation measures. Korup and Tweed (2007) concluded that the stability of landslide dams is a function of their geometry; internal structure; material properties and grain size distribution; volume and rate of water and sediment inflow; and seepage processes. Unfortunately, the internal structure and particle size distribution become evident only after dam failure such that reliably predicting landslide-dam stability remains a key challenge. To overcome this challenge, more efforts should be put in studying the characteristics and stability of typical large-scale landslide dams. In this paper we aim to study a number of representative landslides of various types as well as the corresponding landslide dam features and stability. We then propose a new classification system of landslide dams according to dam composition material and sedimentological features. This classification is linked to the typology of damming landslides and considered to be a preliminary indicator of dam stability. The post-earthquake debris flow damming events induced by subsequent rainfalls are also introduced.

\section{Tectonic and geomorphic setting}

The devastating May 12, $2008\left(M_{w} 7.9\right)$ Wenchuan earthquake was the largest seismic event in China in more than 50 years. It occurred on the NE-trending Longmenshan thrust fault zone (LTFZ) at a focal depth of 14-19 km. The LTFZ separates the Sichuan basin from the steep and heavily dissected eastern margin of the Tibetan Plateau in China. The LTFZ consists of three major sub-parallel faults: the Wenchuan-Maowen (WMF), Yingxiu-Beichuan (YBF) and Pengguan faults (PF) (Fig. 1). The coseismic rupture initiated near Yingxiu town $\left(31.061^{\circ} \mathrm{N}, 103.333^{\circ} \mathrm{E}\right)$ and propagated unilaterally towards the northeast, generating a 240-km long surface rupture along the Yingxiu Beichuan fault, and a $72-\mathrm{km}$ long rupture along the Pengguan fault (Xu et al. 2009b; Lin et al. 2009; Shen et al. 2009).

The elevation of the Longmenshan mountain ranges from $500 \mathrm{~m}$ in the Sichuan Basin to $>5,000 \mathrm{~m}$ over a distance of $\sim 50 \mathrm{~km}$, with tributaries of the Yangtze River flowing oblique or perpendicular from the north or northwest to the south or southeast. Rivers deeply incised in bedrock are flanked by hillslopes commonly $>30^{\circ}$ steep within the LTFZ, and underlain by deformed Paleozoic sediments and metamorphic rocks, Mesozoic sediments, and Precambrian crystalline and metamorphic rocks (Burchfiel et al. 1995; Kirby et al. 2003). The Pengguan 


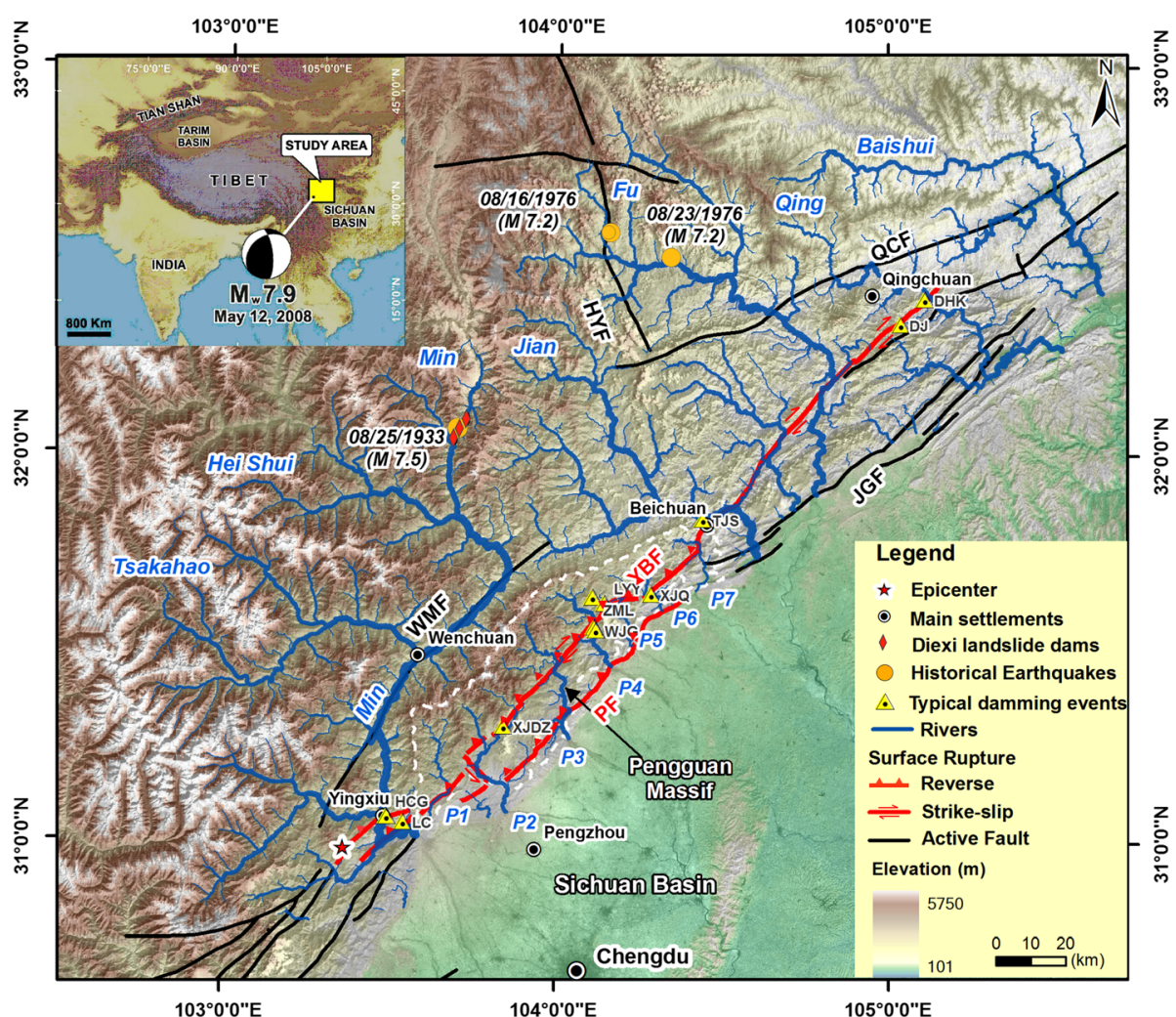

Fig. 1 Study area (inset shows location). Major rivers are shown in blue. The major catchments are: Min river (also called Minjiang), Jian river, Fu river, Qing River, and 7 smaller rivers (P1-P7) in the Pengguan Massif bounded by the white dashed line. WMF: Wenchuan-Maowen fault; YBF: Yingxiu-Beichuan fault; PF: Pengguan fault; JGF: Jiangyou-Guanxian fault; QCF: Qingchuan fault; HYF: Huya fault; MJF: Minjiang fault (after Xu et al. 2009b). Yellow triangles represent the typical coseismic and post-earthquake damming landslides. DGB: Daguangbao landslide, LYY: Laoyingyan landslide, DHK: Donghekou landslide, XJDZ: Xiejiadianzi landslide, XJQ: Xiaojiaqiao landslide, DJ: Dongjia landslide, WJG: Wenjia gully debris flow, ZML: Zoumaling debris flow, HCG: Hongchun gully debris flow, LC: Longchi debris flow

Massif as indicated in Fig. 1 is a Precambrian folded structure that consists mainly of the granitic rocks. Dai et al. (2011) found that Pre-Sinian schist, Cambrian sandstone and siltstone intercalated with slate as well as granitic rocks are more favourable for coseismic landside occurrence.

\section{Methods}

The landslide dam stability largely depends on the dam comprising materials that in turn are strongly related to the types of damming landslides and valley morphometry. The river-blocking landslides triggered by the Wenchuan earthquake can be classified into rock/debris avalanches, debris flows (or landslides of the flow type), rock/debris slides (including deepseated landslides) and rock falls, following the terminology of Cruden and Varnes (1996). This classification is based on landslide failure mechanism and type of movement mainly. In order to avoid a complex classification, types of landslide material were simplified, also because rock and debris are always mixed in the landslide deposits. Field investigation found that most of landslides triggered by the Wenchuan earthquake are bedrock slides. According to the authors' previous study on 828 coseismic landslide dams (Fan et al. 2012c), the proportion of different types of damming landslides is shown in Fig. 2. In this section, a number of representative cases for each type and the

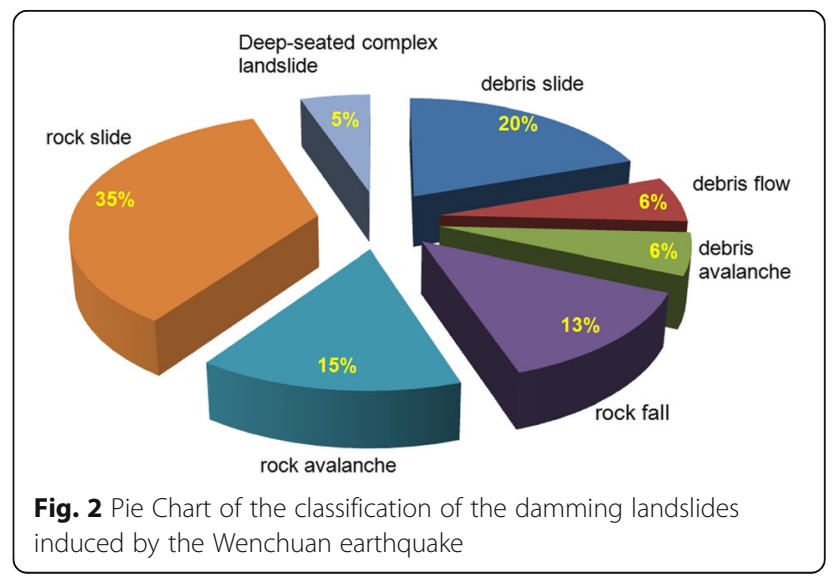


related sedimentological features of the resulting landslide dams are described.

\section{Rock/debris avalanches}

Rock avalanche (also called sturzstrom) was defined by Hsü (1975) as a large bulk of mostly dry rock debris deriving from the collapse of a slope or cliff and moving at a high velocity and for a long distance. Its speed can be in the order of tens of meters per second, the volume in the order of $10^{6} \mathrm{~m}^{3}$. The run-out distance of a rock avalanche often exceeds several kilometers and the mobility becomes visible by the run up on opposite valley slopes. According to these features, we classified the Daguangbao landslide and Laoyingyan landslide as rock avalanches.

\section{(1)Daguangbao landslide}

The most notable example of a coseismic rock avalanche is the Daguangbao landslide, the largest landslide triggered by the Wenchuan earthquake, located in Anxian county, only $6.5 \mathrm{~km}$ from the thrusting part of the Yingxiu-Beichuan fault (Figs. 1 and 3). The source area of the Daguangbao landslide is about $2.4 \mathrm{~km}$ long and $1.2 \mathrm{~km}$ wide, while the deposition area is approximately $3.2 \mathrm{~km}$ long and $2.2 \mathrm{~km}$ wide (Fig. 4). It covers an area of $7.8 \mathrm{~km}^{2}$ and an estimated volume of $840 \times 10^{6} \mathrm{~m}^{3}$
(Chigira et al. 2010) to $1170 \times 10^{6} \mathrm{~m}^{3}$ (Huang and Fan 2013). The sliding mass travelled about $4.5 \mathrm{~km}$ and blocked the Huangdongzi valley, forming a landslide dam nearly $600 \mathrm{~m}$ high. This dam probably is the third highest natural dam in the world, exceeded by the Rondu-Mendi'A' landslide dam with a height of $950 \mathrm{~m}$ along the Indus River in Baltistan, Pakistan (Hewitt 1998) and the Usoi dam with a height of around $700 \mathrm{~m}$ in Tajikistan (Gasiev 1984; Weidinger 1998; Alford et al. 2000; Korup 2002).

The main scarp is serrated and nearly vertical $\left(70^{\circ}-\right.$ $90^{\circ}$ ), with a maximum vertical height of $700 \mathrm{~m}$. The sliding mass crossed the Huangdongzi valley and ran up on the $500 \mathrm{~m}$ high opposite slope, forming many thrust and anti-slope (uphill facing) scarps (Figs. 3 and 4). The strata in the landslide area are mainly composed of carbonates, including the siltstone and mudstone of the Triassic system $(\mathrm{T})$; limestone of the Permian system (P); sandy mudstone of the Carboniferous system (C); dolomite of the Devonian system (D); limestone interbedded mudstone and dolomitic rocks of the Sinian system (Z) as shown in Fig. 4 (Huang et al. 2012). The strata are densely jointed, dipping at $35^{\circ}-38^{\circ}$ towards the valley.

The damming deposits are very heterogeneous with a large range of particle sizes. The top layer of the

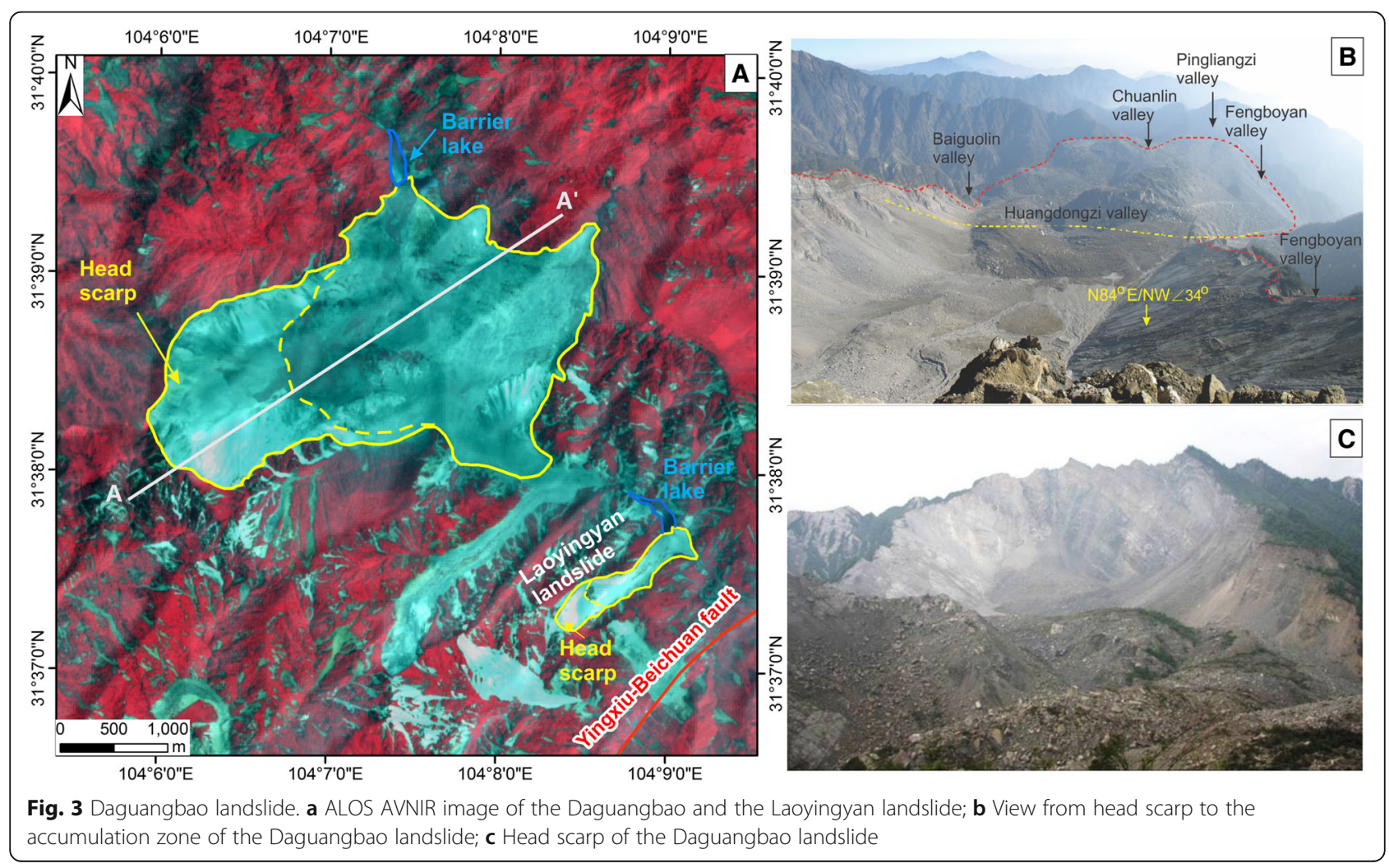




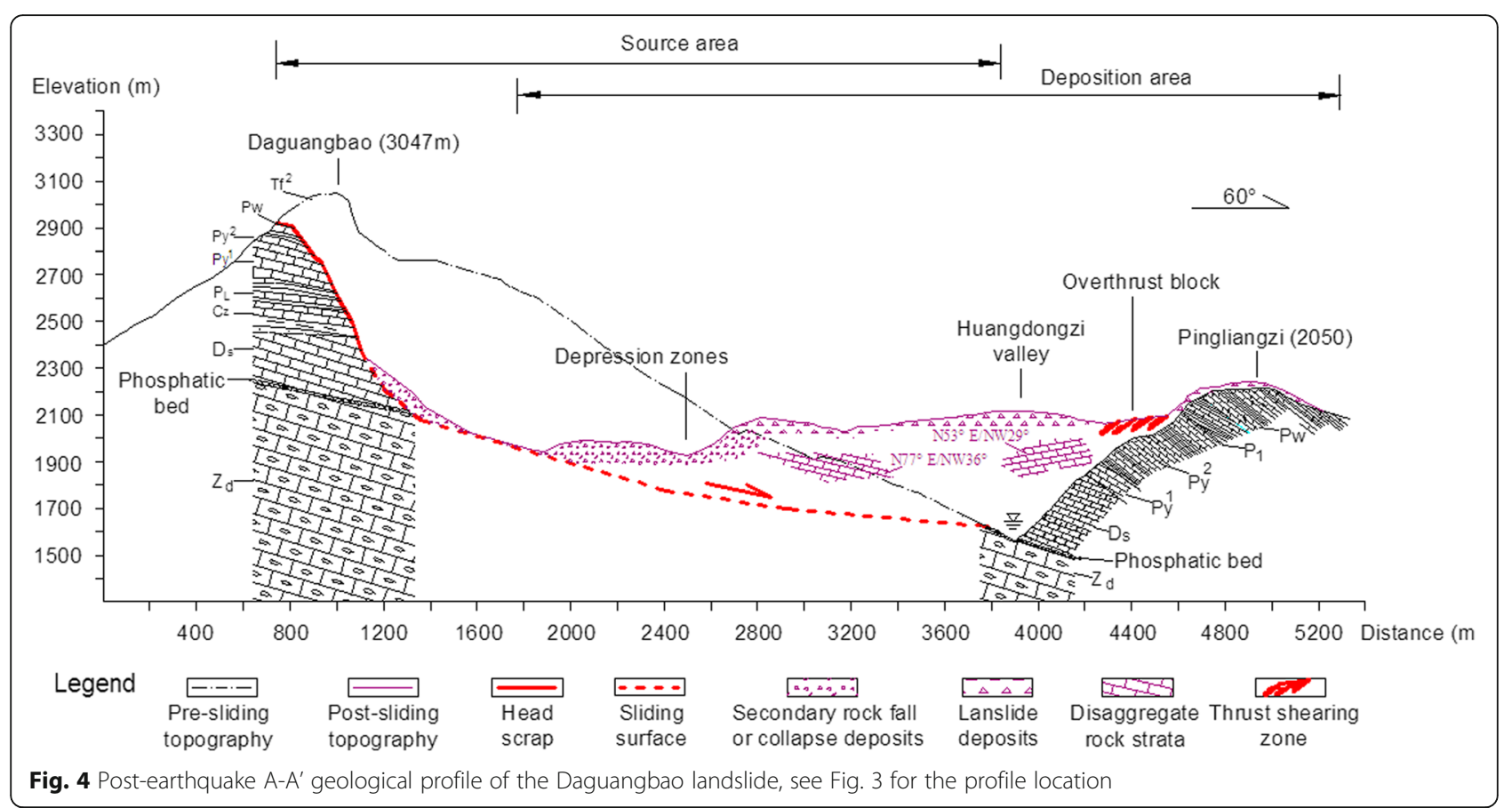

main deposition zone is mainly composed of fine rock fragments and debris mixed with large blocks and boulders with grain sizes varying from $2 \mathrm{~m}$ to $10 \mathrm{~m}$. The middle and bottom layers did not strongly disaggregate, and consist of some almost intact rock masses (Fig. 4). The Daguangbao dam is considered very stable because of its very large size and the rather low discharge of the dammed valley. The occurrence of the Daguangbao landslide and its huge size are controlled by the combined effect of seismic, terrain and geological factors. The landslide is on the hanging wall and very close to the Yingxiu-Beichuan fault. Therefore, it is assumed to have experienced large ground shaking during the earthquake. In addition, the originally steep terrain, the high local relief ( 1600 $\mathrm{m})$, the active tectonics and the densely jointed strata all favour the landslide occurrence. See Huang et al. (2012) for a more detailed explanation of its failure mechanism.

(2)Laoyingyan landslide

The Laoyingyan landslide is located $2.5 \mathrm{~km}$ downstream of the Daguangbao landslide as shown in Fig. 3. About $15 \times 10^{6} \mathrm{~m}^{3}$ rock mass travelled $1 \mathrm{~km}$ and dammed the Huangdongzi valley, forming a $105 \mathrm{~m}$ high dam that impounded a barrier lake with an estimated capacity of $2.2 \times 10^{6} \mathrm{~m}^{3}$ (Figs. 5 and 6). The lake submerged an upstream hydropower station, resulting in more than 20 fatalities. The dam was stabilized by constructing an artificially spillway shortly after the earthquake.
The landslide has a steep $\left(\sim 60^{\circ}\right)$ main scarp about $280 \mathrm{~m}$ high (Figs. 5 and 6). The source rock is the dolomitic limestone mainly with a dip angle of $55^{\circ}-$ $60^{\circ}$. The landslide dam body is mainly composed of large blocks and boulders with an average particle size of $2 \mathrm{~m}$ (accounting for $60-70 \%$ ). The height of one of the large boulders found in the field is about $7 \mathrm{~m}$ (Fig. 6e). The volume of the dam body was estimated to be $8.5 \times 10^{6} \mathrm{~m}^{3}$. The causal factors and failure mechanism of the Laoyingyan landslide are similar to those of the Daguangbao landslide.

\section{Debris flows or landslides of the flow type}

According to the definition of Dikau et al. (1996) and Iverson and Denlinger (2001), debris flows consist of a mixture of fine material (sand, silt and clay), coarse material (gravel and boulders), with a variable quantity of water, which flow rapidly with one or more surges, commonly following pre-existing drainage ways. Three distinctive elements are distinguishable in a debris flow of a flow-type landslide: the source area, the main track (transportation area) and the depositional fan. Debris flows are of primary concern due to their long runout and the resulting destructive impacts. The Donghekou landslide and Xiejiadianzi landslide are two representative coseismic flow-type landslides or debris flows.

(1)Donghekou landslide

The Donghekou landslide located in Qingchuan County, near the northeastern end of the YingxiuBeichuan fault, killed 780 people and blocked the 

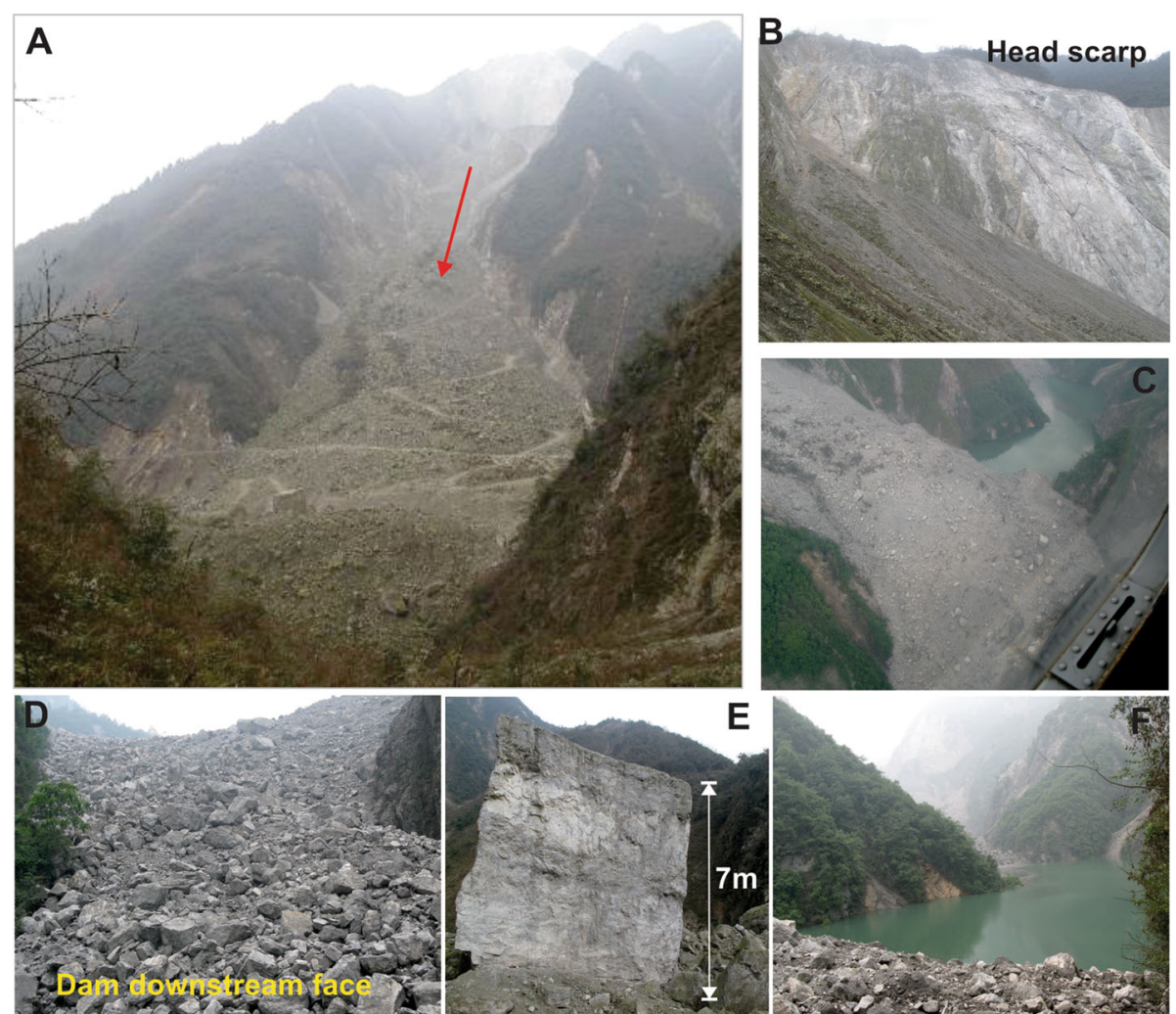

Fig. 5 Laoyingyan landslide. a Overview of the Laoyingyan landslide; b Head scarp; c Helicopter view of the dam body; d Dam downstream face; e: The largest boulder in the deposition zone; and $\mathbf{f}$ Barrier lake

convergence of the Qingzhujiang river and the Hongshi river, forming the Donghekou landslide dam and two barrier lakes (Fig. 7a-d). The dam body is about $20 \mathrm{~m}$ high, $350 \mathrm{~m}$ wide and $750 \mathrm{~m}$ long, with an estimated volume of $12 \times 10^{6} \mathrm{~m}^{3}$
(Fig. 7e). The Hongshihe and the Qingzhujiang barrier lakes have a capacity of $2 \times 10^{6} \mathrm{~m}^{3}$ and $3 \times$ $10^{6} \mathrm{~m}^{3}$, respectively. There is a relatively small debris slide upstream of the Donghekou landslide, the Hongshihe slide, which also dammed the river

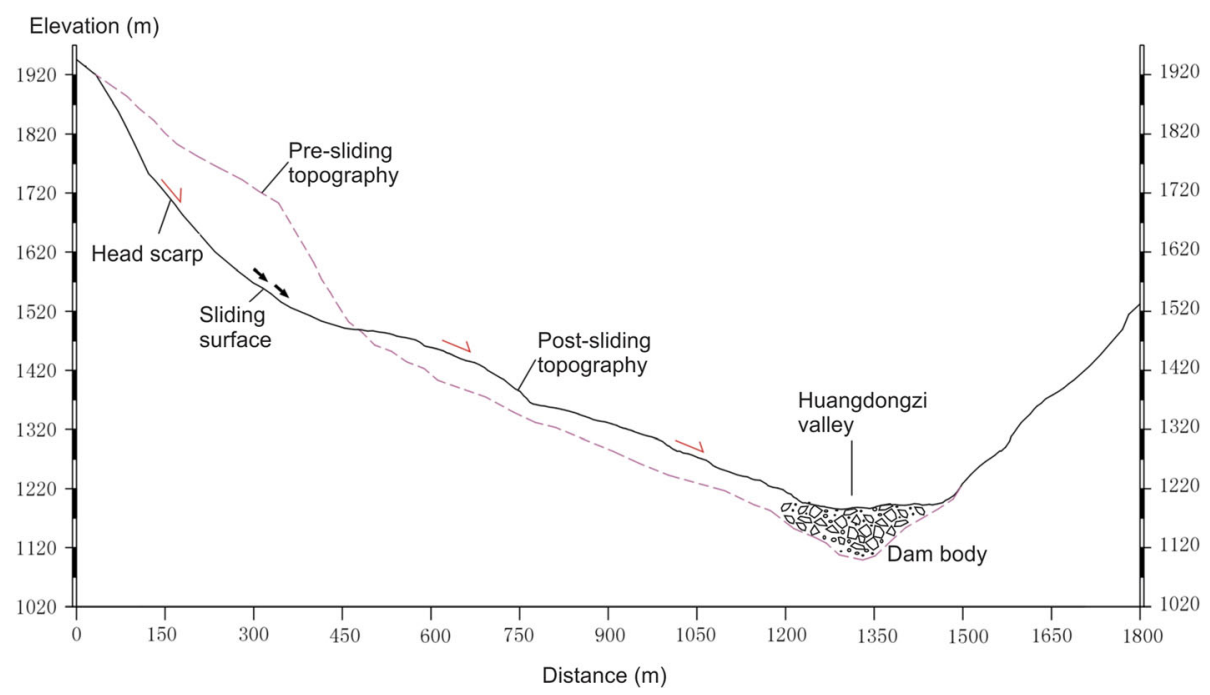

Fig. 6 Typical profile of the Laoyingyan landslide 

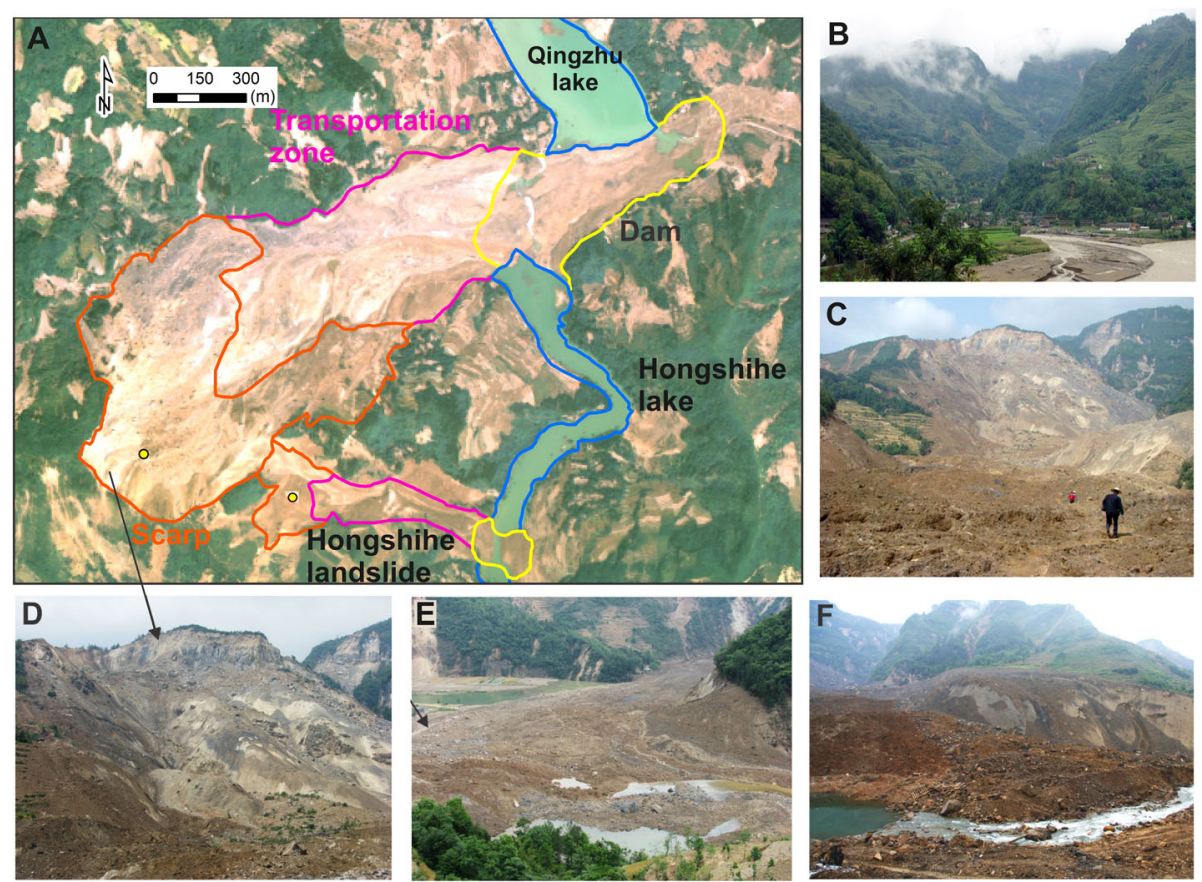

Fig. 7 Donghekou landslide. a Aerial photo of the Donghekou landslide; $\mathbf{b}$ and c Overview photo before and after the earthquake; d Head scarp; e The dam body and two barrier lakes; and $\mathbf{f}$ Artificial spillway

temporally, running up to the other side of the valley for $30 \mathrm{~m}$. The dam was naturally overtopped and eroded shortly after the earthquake due to its weak and loose composition of debris.

The Donghekou landslide was initiated as a rock slide and travelled a vertical distance of $700 \mathrm{~m}$ from $1300 \mathrm{~m}$ to $600 \mathrm{~m}$, over a horizontal distance of $2400 \mathrm{~m}$ into the river (Fig. 8). The angle of reach, defined as the angle of the line connecting the initiation of the landslide source to the distal margin of the landslide deposits, can be estimated as being $16^{\circ}$. Initial failure formed a steep $80 \mathrm{~m}$ high main scarp dipping $50-70^{\circ}$ (Fig. $7 \mathrm{~d}$ ). The source rock is composed of the dolomitic limestone (Yuanji formation of the upper Sinian system), as well as carbonaceous and siliceous slate (Qiujiahe formation, lower Cambrian system). The bedrock is mainly Lower Cambrian sandstone and phyllite. Folds and small sub-faults are well developed in the landslide area.

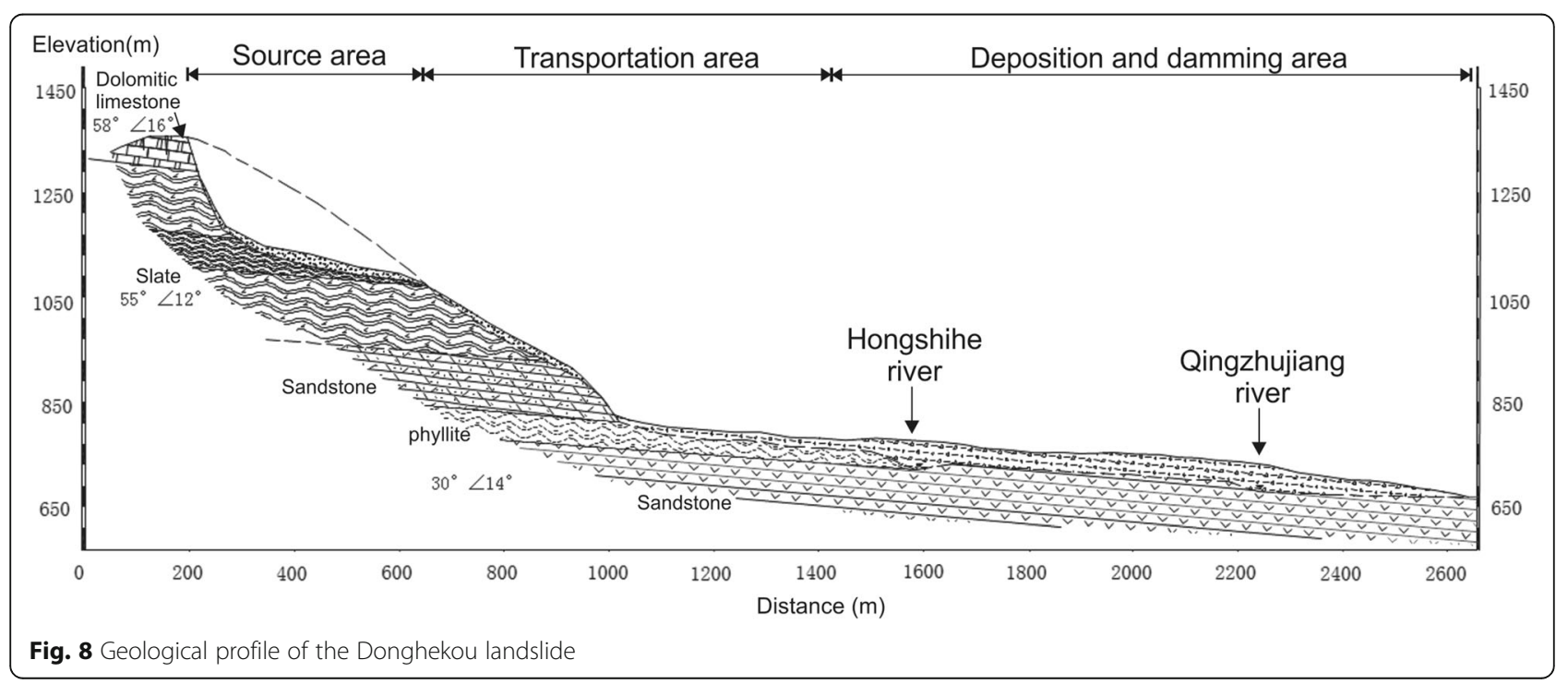


The displaced mass moved down along a mountain gully (Fig. 7b), entraining a large amount of unconsolidated substrate materials and water in the gully, and transforming into a distal flow slide. The grain size of the deposits decreases from the rear to the front of the landslide. Large limestone blocks and boulders are mainly found in the rear of the accumulation area, while the content of fine grained materials increases markedly in the front of the landslide. The dam body was mainly composed of loose soil and fragmented rocks with grain sizes of 30-50 cm. It was dissected artificially by constructing a spillway (Fig. 7f). The landslide failure mechanism analysis and runout dynamic modelling have been done by Sun et al. (2011) and Huang et al. (2012).

(2)Xiejiadianzi landslide

The Xiejiadianzi landslide is a typical debris flow that can be represented by three zones (i.e. source area, transportation zone and deposition zone, Fig. 9). Similar to the Donghekou landslide, it was also initiated as a rock slide and then developed into a debris flow, moving down along a small valley below the source area and causing about 100 deaths. The debris travelled a vertical distance of $660 \mathrm{~m}$ over a horizontal distance of $1230 \mathrm{~m}$ into the river, yielding an angle of reach of $21^{\circ}$. The debris depositional fan blocked the Baishui river, forming a $10 \mathrm{~m}$ high dam that impounded a barrier lake with a maximum capacity of $1.0 \times 10^{6} \mathrm{~m}^{3}$. The initial failure developed in a rock slope composed of the Proterozoic granite mainly, creating a steep main scarp with a height of $80 \mathrm{~m}$ and several smaller secondary scarps. The bedrock in the landslide transportation and deposition zone is mainly feldspathic sandstone of the upper Jurassic system. They are separated by the YingxiuBeichuan fault, passing through the toe of the head scarp (Fig. 9), where a $50 \mathrm{~m}$ wide platform was formed. The volume of the landslide source material and deposits in the fan was estimated as being $0.4 \times 10^{6} \mathrm{~m}^{3}$ and $0.9 \times 10^{6} \mathrm{~m}^{3}$, respectively (Dai et al. 2011). The dam body consists mainly of soil and fragmented rocks with a few large blocks and boulders covering the crest.

Evidences of liquefaction were found in the field, such as reverse grading exposed by valley incision on the fan and the presence of a mudline on the large rock boulders (Fig. 9). Wang et al. (2013) found clayey soils in the basal deposit exposed during road construction 10 months after the earthquake, which were still very soft when exposed, suggesting that the displaced landslide material was transported as a liquefied flow. Chigira et al. (2010) and Dai et al. (2011) observed reverse grading on the fan, indicating that valley fill sediments were mobilized by pore pressure build up or liquefaction.

There are two theories to explain the dynamic mechanism of coseismic debris flows that initiate as a rock slide or fall from a cliff above a gully and then transform into a debris flow:

(1)Rapid undrained loading by the rock slide from above that cause the liquefaction or partial liquefaction of the valley fill (Sassa et al. 1985). It is widely reported that mobility of debris flows is increased by such kind of sudden loading, which also results in the enlargement of debris deposits by entrainment of the liquefied material (i.e. Crosta et al. 2003; Hungr and Evans 2004; Fan and Xu 2010; Iverson et al. 2011).

(2)Long duration of seismic shaking causes liquefaction of valley material. Wang et al. (2013) argued that the main part of the Xiejiadianzi landslide is from the seismogenic liquefaction of the valley colluviums, by performing undrained cyclic shear tests with samples taken from the valley. This might have played a more important role than the rapid undrained loading.

\section{Rock/debris slides}

Rock/debris slides normally occur along a recognisable slip surface, which can be translational (along a nearplanar failure surface) or rotational (along a circular failure surface). Field observations indicate that shallow and deep-seated rock/debris slides account for a large proportion of the slope failures in the study area. The Xiaojiaqiao landslide in Anxian county is a representative deep-seated rock slide, having a vertical and horizontal travel distance of $200 \mathrm{~m}$ and $600 \mathrm{~m}$, respectively (Fig. 10a and b). It formed a $65 \mathrm{~m}$ high dam with an estimated volume of $2.4 \times 10^{6} \mathrm{~m}^{3}$, impounding the second largest barrier lake with a maximum capacity of $22 \times 10^{6} \mathrm{~m}^{3}$.

The head scarp of the landslide is about 160 high and $60^{\circ}$ steep (Fig. 10c). The source rock is composed of Upper Devonian dolomitic limestone, dipping at $40-50^{\circ}$ toward to the valley. The movement of the landslide was constrained by the opposite valley slope, causing that the stratified rock mass did not disintegrate completely. The dam body consists of two layers: the top layer with mainly rock fragments $(\sim 40 \%)$ as well as large boulders and blocks $(\sim 50 \%)$; and the bottom layer with almost intact rock mass (Fig. 10d and e). As the dam has threatened tens of thousands people downstream, it was artificially breached by constructing a spillway to avoid the catastrophic dam-breach flood. 

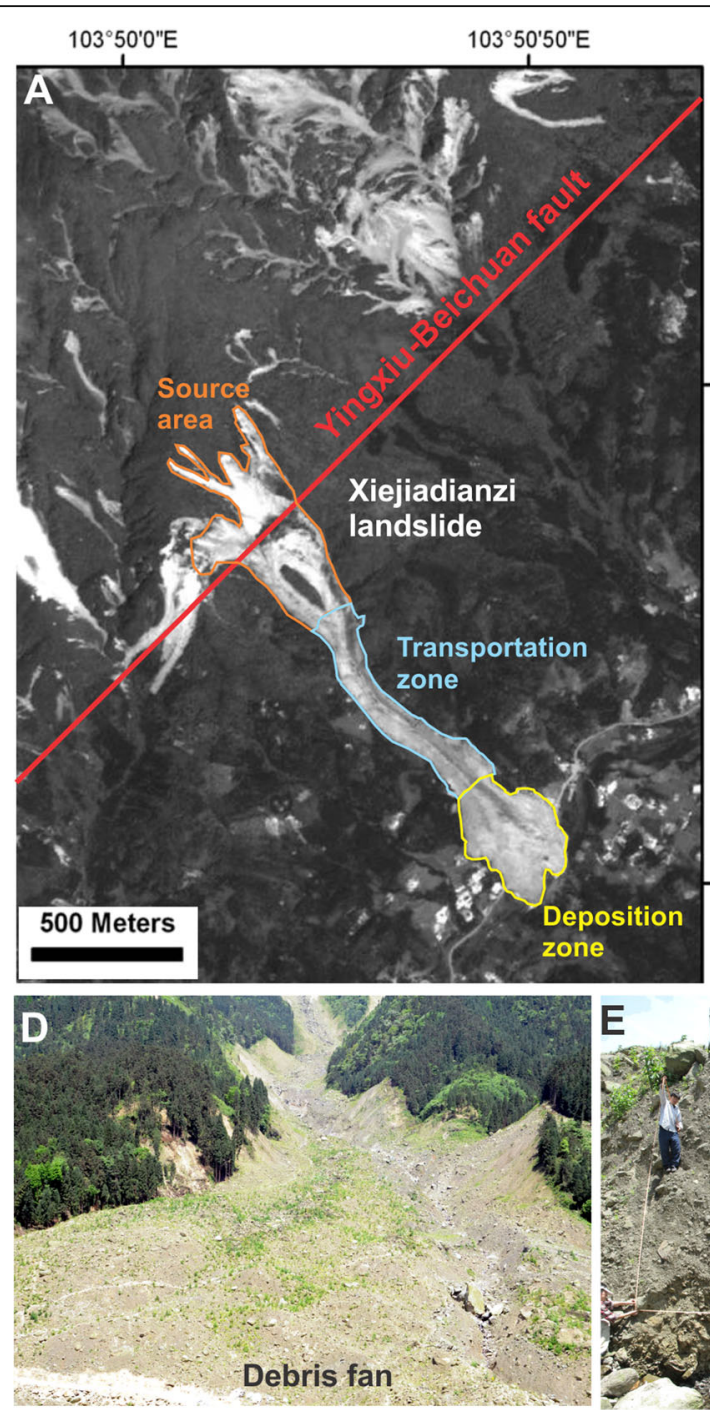

Fig. 9 Xiejiadianzi landslide. a ALOS PRISM Pan image of the Xiejiadianzi landslide; b Overview photo; c Source area; d Depositional zone; e Exposure of the deposits in the debris fan revealed by the valley incision; $\mathbf{f}$ Head scarp, and $\mathbf{g}$ Fine sediments under and mudline on a large block, indicating possible liquefaction phenomenon

\section{Rock falls}

Rock falls are also a major type of coseismic mass movements that mostly occurred in the upper part of slopes due to the topographic amplification effect on seismic waves (Bouchon and Barker 1996), as shown in Fig. 11a. However, only a small proportion of them partially or completely blocked tributaries of main rivers due to their relatively small magnitude and limited runout (Fig. 11b and c). For example, the Dongjia rock fall located in Qingchuan county, dammed a valley and buried 13 people (Fig. 11d and e). The failure rock slope consists mainly of sandy slate that was cut into blocks by a set of near vertical joints (Fig. 11f). A steep head scarp with a height of $76 \mathrm{~m}$ was controlled by these joints. The volume of damming deposits was estimated around $0.88 \times 10^{6} \mathrm{~m}^{3}$,
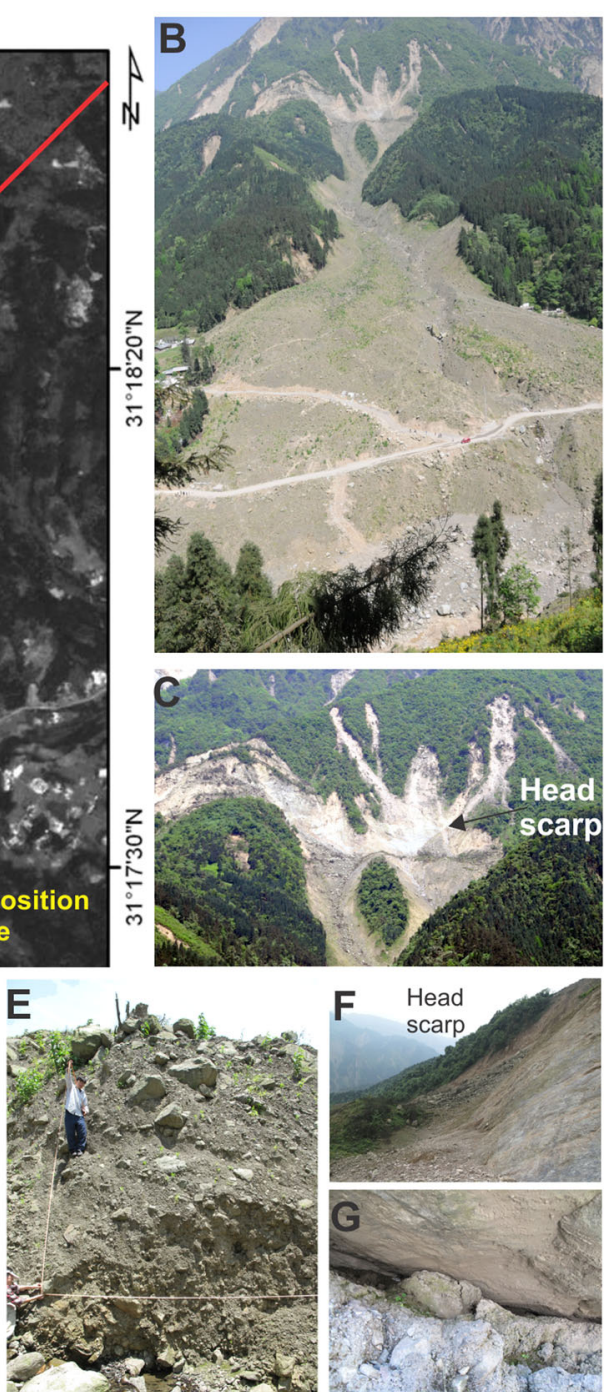

assuming an average thickness of $21 \mathrm{~m}$. The dam body was composed of large boulders (40\%) as well as soil and rock fragments with a grain size of $5-20 \mathrm{~cm}(60 \%)$.

\section{Post-earthquake damming events induced by rainstorms}

Strong earthquakes may produce a large amount of loose sediment from coseismic landslides, which lead to heavy debris flows during post-earthquake rainstorms. Lin et al. (2003) and Chang et al. (2006) evaluated the impact of the Chi-Chi earthquake on the occurrence of post-earthquake debris flows, and concluded that the frequency of debris flows was greatly increased. A number of intense postearthquake landslides and debris flows in the Wenchuan earthquake-hit region were reported. Tang et al. (2011) investigated the landslides and debris flows induced by the 

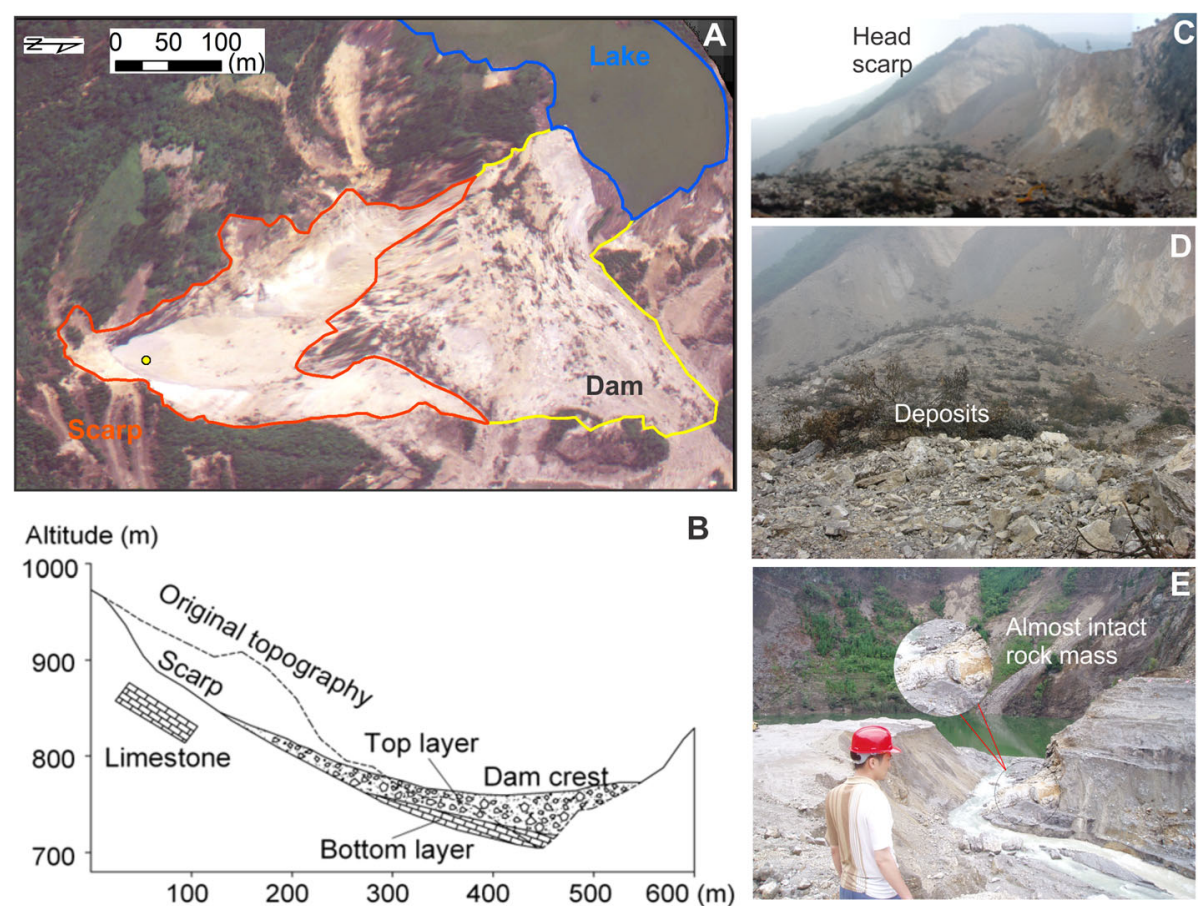

Fig. 10 Xiaojiaqiao landslide. a Aerial photo of the Xiaojiaqiao landslide; b Typical profile of the landslide; c Head scarp; d Depositional zone; and e Exposure of the dam body by an artificial spillway, showing the almost intact rock mass at the bottom

first heavy rainfall four months after the earthquake in the Beichuan region. Xu et al. (2012) studied the debris flows triggered by another heavy rainstorm that occurred during 12-14 August 2010, including the Wenjia gully and Zoumaling gully debris flows in the Qingping catchment, the Hongchun gully debris flow near the town of Yingxiu and the Longchi debris flow near Dujiangyan city, as shown in Fig. 1. According to the record from the Qingping station, the maximum hourly rainfall was about $70 \mathrm{~mm}$, when the debris flow occurred (Xu et al. 2012). The source supply of the Wenjia gully debris flow was from the loose deposits of the second largest coseismic landslide, the Wenjia landslide with an estimated volume of $27.5 \times 10^{6} \mathrm{~m}^{3}$ and runout distance of about $4 \mathrm{~km}$ (Fig. 12a). Massive debris of $4.5 \times 10^{6} \mathrm{~m}^{3}$ covered Qingping town and blocked the Mianyuan river (Fig. 12b). Tang et al. (2011) identified 21 debris flows along the Min river, among which, the Hongchun gully debris flow interrupted the river course and resulted in the flooding of the newly reconstructed Yingxiu town (Fig. 12c and d).

\section{Results}

Regarding landslide dam classification, a geomorphic classification scheme proposed by Swanson et al. (1986) might be the earliest one. This classification was further modified by Costa and Schuster (1988), who classified landslide dams with respect to their geomorphic interactions with the valley floors into six types. It has been recently modified by (Hermanns et al. 2004, 2011) with several additional morphological types. However, these classifications are mainly based on dam geometry with respect to the valley floor, though ignoring dam materials, structure and geotechnical properties, which are widely accepted to play an important role in controlling the landslide dam stability (Casagli and Ermini 2003 and Dunning et al. 2005). There is no standardized classification based on the magnitude and impact of landslide dams or lakes due to the large variation between the small and extremely large events. Therefore, in order to use the landslide dam typology as a preliminary indicator of dam stability, a two-step classification is proposed, based on:

(1) The plan view distribution of landslide deposit within the valley, which is referred to the most widely used classification from Costa and Schuster (1988), including five types as shown in Fig. 13;

Type I: dams which do not span the valley from one valley side to the other;

Type II: dams which span the entire valley floor and may run up the opposite slope;

Type III: dams which span the valley and, in addition, move considerable distances up and down the valley from the failure, and typically involve the largest volume of landslide material; 

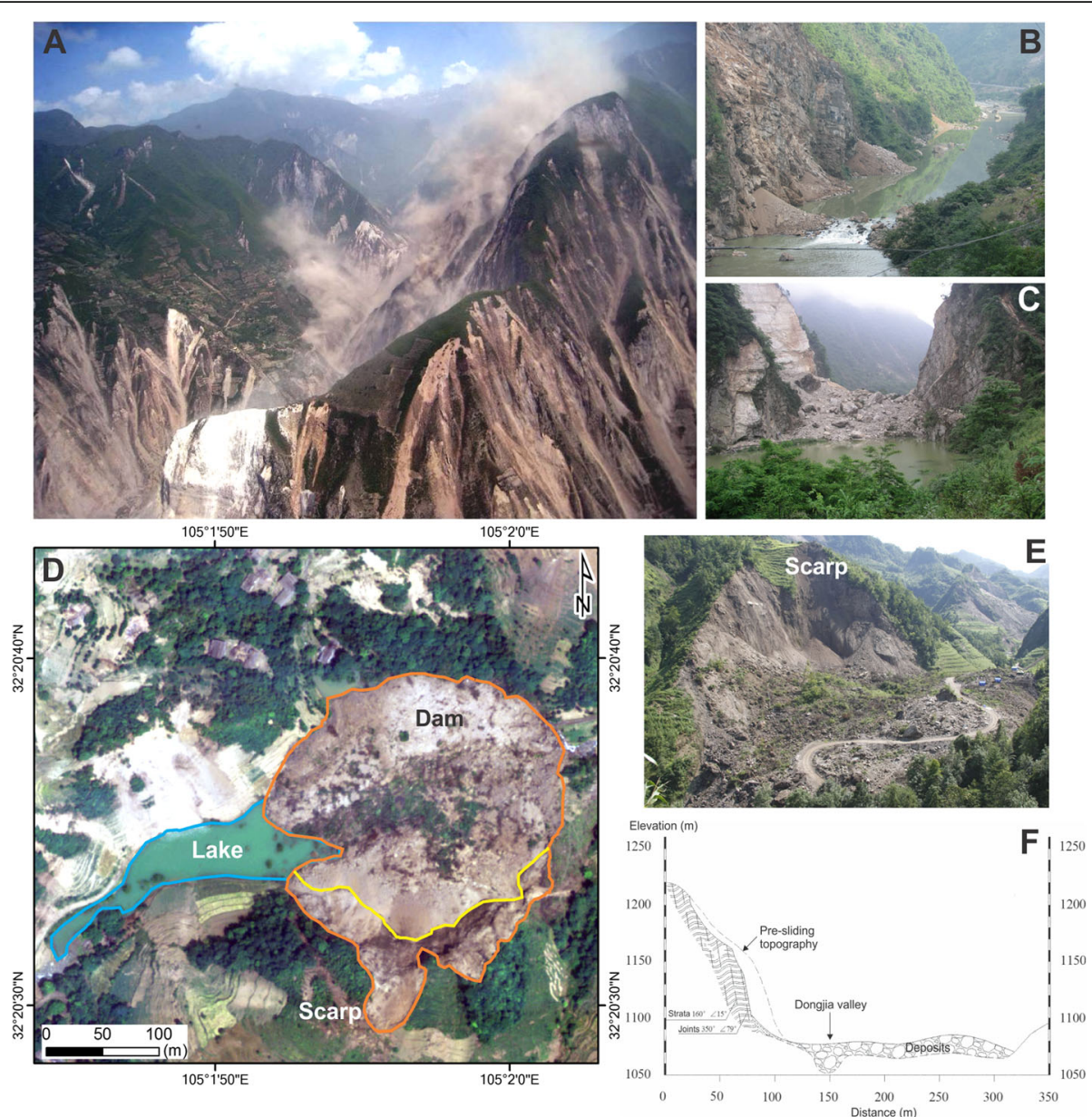

Fig. 11 Rock falls. a Shallow rock falls initiating from the upper part of slopes; b Rock falls interrupted tributaries; $\mathbf{c}$ A damming rock fall; d Aerial photo of the Dongjia rock fall; e Overview photo of the Dongjia rock fall and $\mathbf{f}$ Typical profile of the Dongjia rock fall

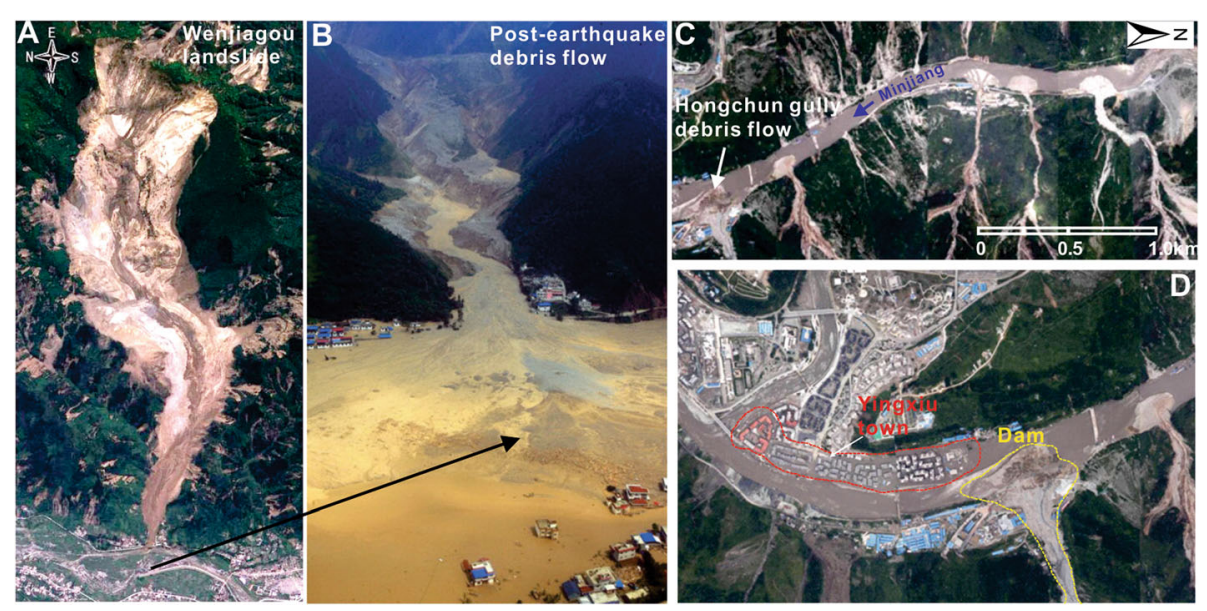

Fig. 12 Post-earthquake debris flow damming events. a Aerial photo of the coseismic Wenjiagou landslide taken on May 18, 2008; b The Qingping debris flow reactivated by heavy rainfall on 12 to 14 August 2010, dammed the Mianyuan river; c Aerial photo of the debris flows along the Minjiang river taken on August 15, 2010; $\mathbf{d}$ Hongchun gully debris flow partially dammed the Minjiang river, causing the flooding of the newly constructed Yingxiu town 


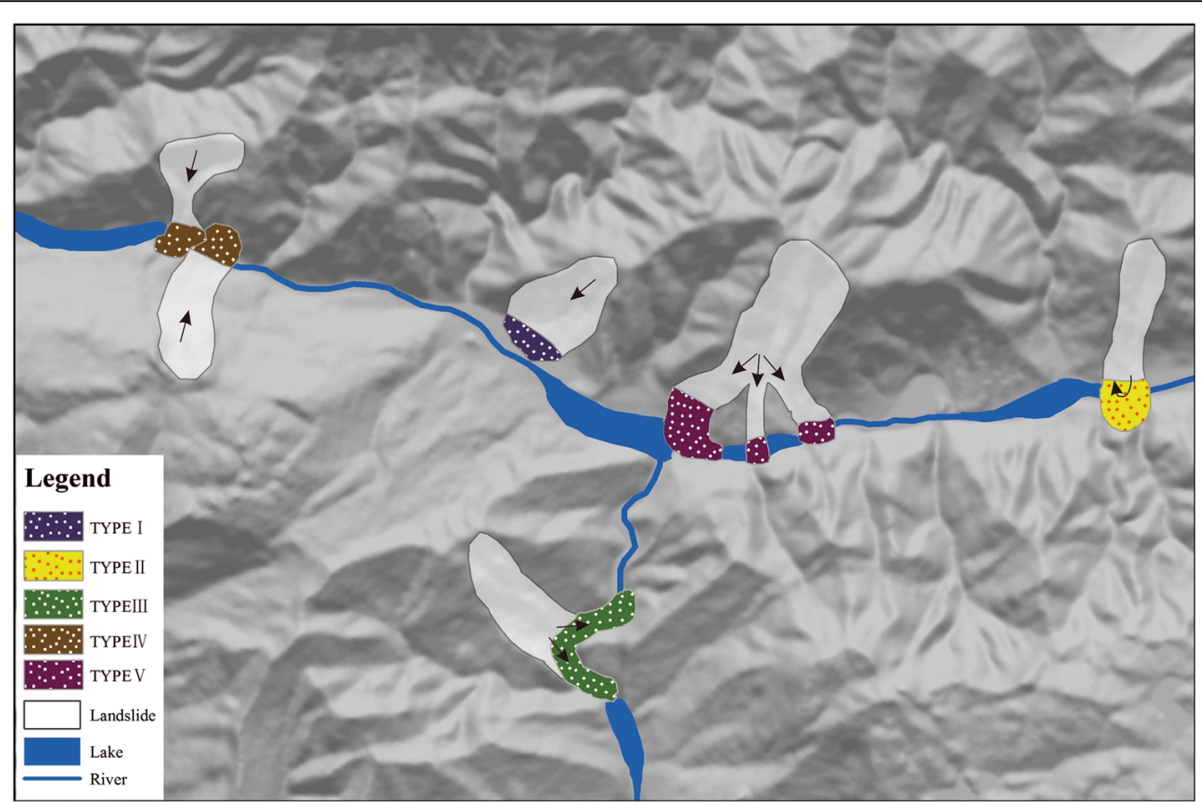

Fig. 13 Five main types of landslide dams based on the geomorphic features of landslide deposits

Type IV: dams which are formed by contemporaneous failures from both valley sides, followed by frontal or slide contact between the two masses;

Type V: dams form when the same landslide has multiple lobes of debris that extend across a valley floor and form two or more landslide dams in the same reach of river;

(2) The dam composition material and sedimentological features. According to the field investigations of more than 30 large landslide dams including aboveintroduced cases, the coseismic landslide dams can be grouped into three sub-types (Fig. 14).

Sub-type I: landslide dams mainly composed of large boulders and blocks. Dams of this type are most probably formed by rock avalanches or rock falls initiating from densely jointed rock slopes, such as the aforementioned Laoyingyan rock avalanche and the Dongjia rock fall. Rock avalanche deposits could also have dual structure with comminuted debris inside overlaid by blocky carapace (Davies and McSaveney 2002).

Sub-type II: landslide dams mainly composed of unconsolidated fine debris, which are usually formed by debris flows, avalanches and slides with long runout and substantial entrainment along their travelling path. The Donghekou and the Xiejiadianzi landslides are good examples of this type. Dams formed by the post-earthquake debris flows mainly belong to this type, showing

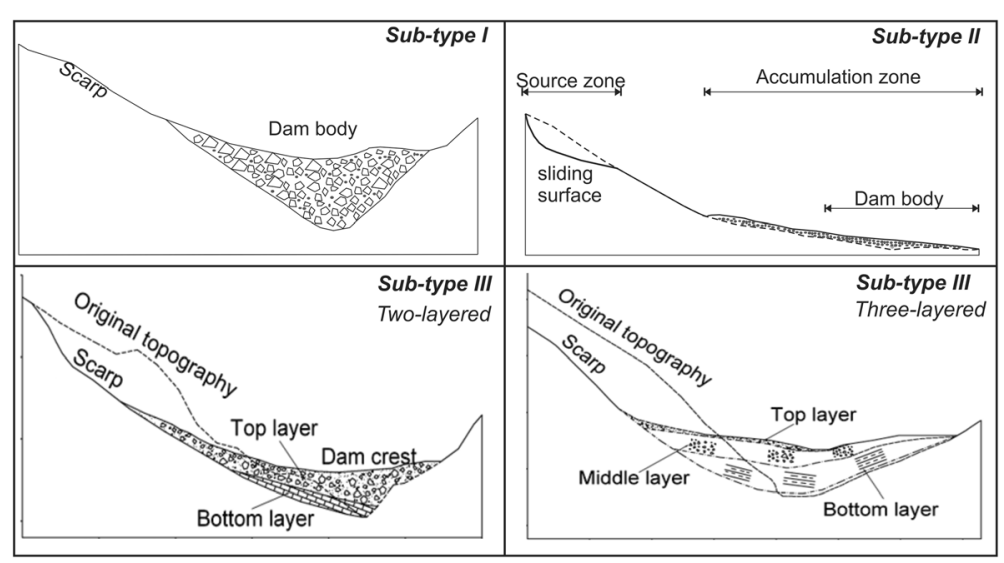

Fig. 14 Three sub-types based on dam composition material and sedimentological features 
a low stability and a high susceptibility to erosion.

Sub-type III: landslide dams with partly intact rock strata at the base topped by large boulders and blocks or soil with rock fragments, showing a two-layered (e.g. the Xiaojiaqiao dam) or three layered (the Tangjiashan dam, Fan et al. 2012b) internal structure. Such dams are mainly formed by deep-seated rock slides or avalanches that fail as a largely intact mass and run into relatively narrow valleys. Due to the topographic constraints on the landslide movement, the sliding rock mass cannot be disintegrated completely, part of which still keeps the original geological structure.

With respect to dam stability, dams of Sub-type III tend to be more consolidated than Sub-type $I$ and $C$, which therefore are less likely to be breached completely. The almost intact rock mass in the dam body can be impermeable, though the fine sediment on the top or middle layer may be eroded due to overtopping. It is believed that dams of Sub-type I composed of boulders and blocks are less likely to fail than those of Sub-type II containing unconsolidated or highly permeable debris (Costa and Schuster 1988; Korup and Tweed 2007). In addition, dam stability is related to landslide runout distance as well. Landslides with long runout distance are more likely to be disintegrated and fragmented during the travelling process. The behaviour of landslide dams is also strongly linked to their geometry that is determined mainly by the landslide volume and valley geomorphometry. In general, the broader a valley, the shallower a dam and more likely for the dam to be overtopped and breached.

\section{Discussion and conclusions}

Fundamentally, earthquakes affect the stability of slopes in two ways: (1) the ground shaking may reduce the frictional strength of the substrate by shattering of rock mass or liquefaction; and (2) the seismic acceleration may result in short-lived and episodic changes of the tensile and shear stresses in the hillslopes during earthquakes. Meunier et al. (2008) mentioned that these changes may be sufficient to cause failure. Based on the field investigation and above case studies, the failure mechanism of the landslides triggered by the Wenchuan earthquake can also be explained by these two aspects.

First, the widespread shattering has been found in many coseismic landslides in the study area, and appears to be especially severe in slopes on the hanging wall (Huang and Li 2009 and Chigira et al. 2010). It has also been reported from the epicentral area of many earthquakes (Brune 2001). Numerous cracks were found in many coseismic landslides, reflecting the intensive shattering and cracking. The long duration seismic shaking can largely reduce the shear strength of the substrate and even cause liquefaction of saturated material in some cases (e.g. the Xiejiadianzi landslide). Liquefaction phenomena have also been observed in other earthquake regions, for example, in the San Francisco Bay area during the 1989 Loma Prieta earthquake (Kayen et al. 1998) and in Niigata, Japan during the 2004 Mid-Niigata Prefecture earthquake (Sassa 2005).

Second, tensile stress caused by the strong ground shaking mainly appeared in the crown of landslides, where the peak ground acceleration (PGA) is supposed to be the largest due to the topographic amplification (Bouchon and Barker 1996). The rock mass is subjected to fail by tensile force due to their low tensile resistance strength. As a result, coseismic landslides often have high and steep head scarps. Meanwhile the seismic shaking also contributes to the shear stress (sliding force) along the sliding zone. Eventually, when the sliding force exceeds the resistance force, a landslide will happen.

In addition, the tectonic and geological structure of the area was also found to be a dominating factor of coseismic landslide occurrence. Most of the investigated landslides were initiated from densely-jointed rock slopes. Dai et al. (2011) studied several rock avalanches triggered by the Wenchuan earthquake with the seismogenic fault traversing their source areas, and found that the shearing and brecciation associated with the preceding fault movement, rendering the rock slopes prone to failure.

The classification of landslide dams proposed in this study can be used as a preliminary indicator of dam stability. More reliable assessment requires a geotechnical approach taking into account a variety of dynamic loading scenarios, and also relies on knowledge about the accurate dam and barrier-lake geometry (Risley et al. 2006; Korup and Tweed 2007). There is still a large amount of loose sediment remaining on the slopes, which may be reactivated and remobilized during the heavy post-earthquake rainstorms. Therefore, predicting the post-earthquake debris flows and evaluating their potential for damming rivers are still of great concern and remain as a main challenge.

\footnotetext{
Acknowledgements

The authors thank the two reviewers whose comments and suggestions contributed to the improvement of the manuscript. The authors also thank master students for helping in the field investigation: Qing Yang, Lanxin Dai and Jing Ren.
}

\section{Funding}

This research was financially supported by Funds for Creative Research Groups of China (Grant No. 41521002), the Young Scientists Fund of the National Natural Science Foundation of China (No. 41302241), the Fund from Land and Resources Department of Sichuan Province (Grant No. KJ-2015-01), the Resilience to Earthquake-induced landslide risk in China (Grant No. 41661134010), and the Fok Ying-Tong Education Foundation for Young Teachers in the Higher Education Institutions of China (151018). 


\section{Authors' contributions}

XF conceived and structured the whole manuscript. QX, CJW and RH supervised the writing, selected the most representative landslide and landslide dam cases, suggested the classification methods. RT did the field survey and data collection. All authors read and approved the final manuscript.

\section{Competing interests}

The authors declare that they have no competing interests.

\section{Publisher's Note}

Springer Nature remains neutral with regard to jurisdictional claims in published maps and institutional affiliations.

\section{Author details}

${ }^{1}$ The State Key Laboratory of Geohazards Prevention and Geoenvironment Protection, Chengdu University of Technology, Chengdu, Sichuan, China610059. ${ }^{2}$ Faculty of Geo-Information Science and Earth Observation (ITC), University of Twente, 7500 AE EnschedeP.O. Box 217The Netherlands.

\section{Received: 19 November 2016 Accepted: 30 March 2017}

\section{Published online: 04 April 2017}

\section{References}

Alford, D., S.F. Cunha, and J.D. Ives. 2000. Lake Sarez, Pamir Mountains, Tajikistan: mountain hazards and development assistance. Mountain Research and Development 20: 20-23.

Asanza, M, Plaza-Nieto, G, Yepes, H, Shuster, R, and Ribadeneira, S. 1992. Landslide blockage of the Pisque river, northern Ecuador, in Proceedings Landslides. Glissements de terrain. Proceedings of the sixth international symposium:10-14.

Bouchon, M., and J.S. Barker. 1996. Seismic response of a hill: the example of Tarzana, California. Bulletin of the Seismological Society of America 86(1A): 66-72.

Brune, J.N. 2001. Shattered rock and precarious rock evidence for strong asymmetry in ground motions during thrust faulting. Bulletin of the Seismological Society of America 91(3): 441-447.

Burchfiel, B.C., C. Zhiliang, L. Yupinc, and L.H. Royden. 1995. Tectonics of the longmen shan and adjacent regions, Central China. International Geology Review 37(8): 661-735.

Casagli, N., and L. Ermini. 2003. Determining grain size distribution of the material composing landslide dams in the Northern Apennines: sampling and processing methods. Engineering Geology 69: 83-97.

Chang, KJ., A. Taboada, Y.C. Chan, and S. Dominguez. 2006. Post-seismic processes in the Jiufengershan landslide area, 1999 Chi-Chi earthquake epicentral zone, Taiwan. Engineering Geology 86: 102-117.

Chigira, M., X. Wu, T. Inokuchi, and G. Wang. 2010. Landslides induced by the 2008 Wenchuan earthquake, Sichuan, China. Geomorphology 118(34): $225-238$

Costa, J.E., and R.L. Schuster. 1988. The formation and failure of natural dams. Geological Society of America Bulletin 100: 1054-1068.

Crosta, G., P. Dal Negro, and P. Frattini. 2003. Soil slips and debris flows on terraced slopes. Natural Hazards and Earth System Sciences 3(1-2): 31-42.

Cruden, D.M., and D.J. Varnes. 1996. Landslide types and processes. In Landslides, investigation and mitigation: special report, transportation research board, national research council, vol. 247, ed. A.K. Turner and R.L. Schuster, 36-75.

Cui, P., Y.Y. Zhu, Y.S. Han, X.Q. Chen, and J.Q. Zhuang. 2009. The 12 May Wenchuan earthquake-induced landslide lakes: distribution and preliminary risk evaluation. Landslides 6: 209-223.

Dai, F.C., C. Xu, X. Yao, L. Xu, X.B. Tu, and Q.M. Gong. 2011. Spatial distribution of landslides triggered by the 2008 Ms 8.0 Wenchuan earthquake, China. Journal of Asian Earth Sciences 40(4): 883-895.

Davies, T., and M. McSaveney. 2002. Dynamic simulation of the motion of fragmenting rock avalanches. Canadian Geotechnical Journal 39(4): 789-798.

Dikau, R., Brunsden, D., Schrott, L., Ibsen, M.L. (1996) Landslide recognition: movement and Courses. New York: Wiley. ISBN: 0-471-96477-8,210pp.

Dunning, S.A., D.N. Petley, and N.J. Rosser. 2005. In The morphology and sendimentology of valley confined rock-avalanche deposits and their effect on potential dam hazard: landslide risk management, ed. O. Hungr, R. Fell, R. Couture, and E. Eberhardt. London: Taylor \& Francis Group.

Ermini, L., and N. Casagli. 2003. Prediction of the behaviour of landslide dams using a geomorphological dimensionless index. Earth Surface Processes and Landforms 28(1): 31-47.
Evans, S., K. Delaney, R. Hermanns, A. Strom, and G. Scarascia-Mugnozza. 2011. The formation and behaviour of natural and artificial rockslide dams; implications for engineering performance and hazard management. In Natural and artificial rockslide dams, 133, ed. S.G. Evans, R.L. Hermanns, A. Strom, and G. Scarascia-Mugnozza, 1-75. Berlin Heidelberg: Springer.

Fan, X., and Q. Xu. 2010. Xiejiadianzi landslide, Pengzhou. In Large-scale landslides induced by the Wenchuan earthquake, ed. Q. Xu, X. Pei, and R. Huang, 407422. Beijing: Science Press. book chapter in Chinese.

Fan, X., C.J. van Westen, Q. Xu, T. Görüm, and F. Dai. 2012a. Analysis of landslide dams induced by the 2008 Wenchuan earthquake. Journal of Asian Earth Sciences 57: 25-37.

Fan, X., C.X. Tang, C.J. van Westen, and D. Alkema. 2012b. Simulating dam-breach scenarios of the Tangjiashan landslide dam induced by the Wenchuan earthquake. Natural Hazards and Earth System Sciences 12: 3031-3044.

Fan, X., C.J. van Westen, O. Korup, T. Görüm, Q. Xu, F. Dai, R. Huang, and G. Wang 2012c. Transient water and sediment storage of the decaying landslide dams induced by the 2008 Wenchuan earthquake, China. Geomorphology 171-172: 58-68.

Gasiev, E. 1984. Study of the Usoy landslide in Pamir, in Proc: 4th Int'l. Symp. on Landslides. Toronto (1): 511-515.

Hermanns, R., R. Naumann, A. Folquera, and A. Pagenkopf. 2004. Sedimentologic analyses of deposits of a historic landslide dam failure in Barrancas valley causing the catastrophic 1914 Rio Colorado flood, northern Patagonia, Argentina. Landslides: evaluation and stabilization, Balkema 2: 1439-1445.

Hermanns, R.L., K. Hewitt, A.L. Strom, E.G. Evans, S.A. Dunning, and G. ScarasciaMugnozza. 2011. The classification of rock slide dams. In Natural and artificial rockslide dams. lecture series in earth sciences, ed. S.G. Evans, R.L. Hermanns, A. Strom, and G. Scarascia Mugnozza, 581-593. Berlin: Springer.

Hewitt, K. 1998. Catastrophic landslides and their effects on the upper Indus streams, Karakoram Himalaya, northern Pakistan. Geomorphology 26(1-3): 47-80.

Hsü, K.J. 1975. Catastrophic debris streams (sturzstroms) generated by rockfalls. Geological Society of America Bulletin 86(1): 129-140.

Huang, R., and X. Fan. 2013. The landslide story. Nature Geoscience 6(5): 325-326.

Huang, R.Q., and W.L. Li. 2009. Analysis of the geo-hazards triggered by the 12 May 2008 Wenchuan earthquake, China. Bulletin of Engineering Geology and the Environment 68(3): 363-371.

Huang, R., X. Pei, X. Fan, W. Zhang, S. Li, and B. Li. 2012. The characteristics and failure mechanism of the largest landslide triggered by the Wenchuan earthquake, May 12, 2008, China. Landslides 9(1): 131-142.

Hungr, O., and S. Evans. 2004. Entrainment of debris in rock avalanches: an analysis of a long run-out mechanism. Geological Society of America Bulletin 116(9-10): 1240-1252.

Iverson, R.M., and R.P. Denlinger. 2001. Flow of variably fluidized granular masses across three-dimensional terrain: 1. Coulomb mixture theory. Journal of Geophysical Research 106(B1): 537-552.

Iverson, R.M., M.E. Reid, M. Logan, R.G. LaHusen, J.W. Godt, and J.P. Griswold. 2011. Positive feedback and momentum growth during debris-flow entrainment of wet bed sediment. Nature Geoscience 4(2): 116-121.

Kayen, R., J. Mitchell, R. Seed, and S. Nishio. 1998. Soil liquefaction in the east bay during the earthquake: US geological survey professional paper, 1551B.

Kirby, E., K.X. Whipple, W. Tang, and Z. Chen. 2003. Distribution of active rock uplift along the eastern margin of the Tibetan Plateau: inferences from bedrock channel longitudinal profiles. Journal of Geophysical Research: Solid Earth 108(B4): 2217.

Korup, O. 2002. Recent research on landslide dams-a literature review with special attention to New Zealand. Progress in Physical Geography 26: 206-235.

Korup, O. 2004. Geomorphometric characteristics of New Zealand landslide dams. Engineering Geology 73: 13-35.

Korup, O., and F. Tweed. 2007. Ice, moraine, and landslide dams in mountainous terrain. Quaternary Science Reviews 26(25): 3406-3422.

Lin, J., J. Lin, and J. Lee. 2003. Hazard assessment of potential debris flows in the watershed of Chen-Yu-Lan river. In Proceedings Proceedings of the Third International Conference on Debris-Flow Hazards Mitigation, Davos, Switzerland, vol. 90, 78. Rotterdam: Millpress.

Lin, A., Z. Ren, D. Jia, and X. Wu. 2009. Co-seismic thrusting rupture and slip distribution produced by the $2008 \mathrm{Mw} 7.9$ Wenchuan earthquake, China. Tectonophysics 471(3-4): 203-215.

Liou, Y.-A., S.K. Kar, and L. Chang. 2010. Use of high-resolution FORMOSAT-2 satellite images for post-earthquake disaster assessment: a study following the 12 May 2008 Wenchuan EArthquake. International Journal of Remote Sensing 31(13): 3355-3368. 
Liu, N., J.X. Zhang, W. Lin, W.Y. Cheng, and Z.Y. Chen. 2009. Draining Tangjiashan barrier lake after Wenchuan earthquake and the flood propagation after the dam break. Science in China Series E-technological Sciences 52(4): 801-809.

Meunier, P., N. Hovius, and J.A. Haines. 2008. Topographic site effects and the location of earthquake induced landslides. Earth and Planetary Science Letters 275(3-4): 221-232.

Peng, M., and L.M. Zhang. 2012. Breaching parameters of landslide dams. Landslides 9(1): 13-31.

Risley, J.C., J.S. Walder, and R.P. Denlinger. 2006. Usoi dam wave overtopping and flood routing in the Bartang and Panj Rivers, Tajikistan. Natural Hazards 38(3): 375-390.

Sassa, K. 2005. Landslide disasters triggered by the (2004) Mid-Niigata Prefecture earthquake in Japan. Landslides 2(2): 135-142

Sassa, K, Kaibori, M, and Kitera, N. 1985. Liquefaction and undrained shear of torrent deposits as the cause of debris flows, in Proceedings Proceedings International Symposium on Erosion, Debris Flows and Disaster Prevention: 231-236.

Schuster, R.L. 1993. Landslide dams - a worldwide phenomenon. Proceedings annual symposium of The Japanese Landslide Society, Kansai Branch, 27 April, Osaka.

Shen, Z.-K., J. Sun, P. Zhang, Y. Wan, M. Wang, R. Burgmann, Y. Zeng, W. Gan, H. Liao, and Q. Wang. 2009. Slip maxima at fault junctions and rupturing of barriers during the 2008 Wenchuan earthquake. Nature Geosci 2(10): 718-724.

Sun, P., Y. Zhang, J. Shi, and L. Chen. 2011. Analysis on the dynamical process of Donghekou rockslide-debris flow triggered by 5.12 Wenchuan earthquake. Journal of Mountain Science 8(2): 140-148.

Swanson, FJ, Oyagi, N, and Tominaga, M. 1986. Landslide dams in Japan, in Proceedings Landslide Dams@ sProcesses, Risk, and Mitigation. (ASCE):131-145.

Tang, C., J. Zhu, X. Qi, and J. Ding. 2011. Landslides induced by the Wenchuan earthquake and the subsequent strong rainfall event: a case study in the Beichuan area of China. Engineering Geology 122(1-2): 22-33.

Wang, G., F. Liu, X. Fu, and T. Li. 2008. Simulation of dam breach development for emergency treatment of the Tangjiashan Quake Lake in China. Science in China series E: Technological Sciences 51(2): 82-94.

Wang, G., R. Huang, M. Chigira, X. Wu, and S.D.N. Lourenco. 2013. Landslide amplification by liquefaction of runout-path material after the 2008 Wenchuan (M 8.0) earthquake, China. Earth Surface Processes and Landforms 38: 265-274.

Weidinger, J.T. 1998. Case history and hazard analysis of two lake-damming landslides in the Himalayas. Journal of Asian Earth Sciences 16: 323-31.

Xu, Q., X.M. Fan, R.Q. Huang, and C.J. van Westen. 2009a. Landslide dams triggered by the Wenchuan earthquake, Sichuan Province, south west China. Bulletin of Engineering Geology and the Environment 68(3): 373-386.

Xu, X., X. Wen, G. Yu, G. Chen, Y. Klinger, J. Hubbard, and J. Shaw. 2009b. Coseismic reverse- and oblique-slip surface faulting generated by the 2008 Mw 7.9, Wenchuan earthquake, China. Geology 37(6): 515-518.

Xu, M., C. Cao, H. Zhang, J. Guo, K. Nakane, Q. He, J. Guo, C. Chang, Y. Bao, and M. Gao. 2010. Change detection of an earthquake-induced barrier lake based on remote sensing image classification. International Journal of Remote Sensing 31(13): 3521-3534

Xu, Q., Y. Shang, T. van Asch, S. Wang, Z. Zhang, and X. Dong. 2012. Observations from the large, rapid Yigong rock slide - debris avalanche, southeast Tibet. Canadian Geotechnical Journal 49(5): 589-606.

\section{Submit your manuscript to a SpringerOpen ${ }^{\circ}$ journal and benefit from:}

- Convenient online submission

- Rigorous peer review

- Immediate publication on acceptance

- Open access: articles freely available online

- High visibility within the field

- Retaining the copyright to your article 